\title{
12 Family firms and corporate spatial responsibilities in Germany
}

\author{
Implication for urban and \\ regional planning and \\ management
}

\section{Hans-Hermann Albers and Lech Suwala}

\section{Introduction}

The planning and management of urban and rural areas has always consisted of a mixture of state-market relations and civil society. This trend has accelerated over the preceding decades as liberalization, deregulation and privatization of former state-performed tasks has increased, the institutional capacities of smaller communities have declined, and as regionally consolidated public administrations have become less effective (leading in extreme cases to failed states). During this time, much responsibility has shifted to non-state actors in general to participate in 'place-based' economic engagement; private sector and family firms in particular have been encouraged to become more involved in regional development and other governance schemes (Harrison, 2014; Suwala, Kulke, \& Gade, 2018; Basco, Stough, \& Suwala, 2020). This chapter attempts to analyze this phenomenon by offering a unique perspective on urban and regional engagement as it is driven by family firms. It does so by connecting two evolving discourses: On the one hand, on spatial distributions and characteristics of family firms (Basco, 2015; Stough et al., 2015; Basco \& Suwala, 2020a, b), and on the other hand, on corporate spatial responsibilities $(\mathrm{CSpR})$ - a spatial expansion of the well-known corporate social responsibility phenomenon (Albers, 2011; Knieling, Othengrafen, \& Preising, 2012; Albers \& Suwala, 2018; Albers \& Suwala, 2020a; Suwala \& Albers, 2020).

This chapter summarizes selected existing case studies of such family firm-driven urban and regional engagement from literature and asks how (forms) and to what extent (their spatial impact/intensity) family firms implement CSpR initiatives. In other words, the chapter seeks to establish whether cases from the one discourse can be translated into the conceptual schemes of the other; can family firms be viewed as "spatially responsible"? To operationalize this analysis, we apply the so-called 'CSpR maturity model' (Albers \& Suwala, 2018) to family firms involved in spatial development in their areas. The cases in this chapter are pulled from data in existing 
literature, from the authors' previous research and from a personal selection of case studies of spatially engaged family firms (e.g., Albers, 2011; Albers \& Suwala, 2018). We intend to use "purposive sampling" (Patton, 2001) and focus on "polar types" (Meredith, 1998) in order to showcase the diversity and wide variety of applicable cases.

Our results show that family firms engage with their environments in many ways and with varying degrees of spatial commitment. Family firms sponsor the development of social, educational and recreational infrastructure and facilities. They participate in district renewal, offer privately owned resources for public use, contribute to business improvement districts, are involved in town center management and lead master plan initiatives, among other activities. At the same time, they participate in spatial responsibility to different degrees of intensity. Some initiatives, similar to traditional corporate social responsibility measures, are limited in their spatial impacts (for example, donations, sponsorships, patronage and charity involvement); these are still the most common forms of outreach for family firms. Others engage in more complex measures, including joining public-private partnerships, cooperating on projects with public and civil sector actors and investing in long-term interinstitutional projects. These latter cases demonstrate the potential for targeted spatial engagement by family firms. In some cases, family firms even take state functions and exert place leadership, as in cases of firm-driven master plan initiatives.

This chapter sheds light on the importance of family firms as active stakeholders in urban/regional planning and management, a topic widely neglected in related academic literature. In this vein, policy-makers should not only consider family firms as an equivalent member in the enlarged orchestra of stakeholders involved in regional planning and management, but also need to understand and anticipate their interest in participating in regional policies and the advantages that can derive from these initiatives. Family firms are already widely 'entangled' in their regions, with personal and professional ties and commitments to their surroundings. Our research proposes strategies for unleashing the significant and often latent potential of family firms, in particular by recognizing shared interests and developing common objectives between them and the regions in which they are situated.

The chapter is organized as follows: Section 2 summarizes the 'state of the field' with regard to family firms in spatial contexts and CSpR, and points to synergies while linking both disciplines; Section 3 encompasses the main analysis by showcasing different CSpR types and intensities of family firm-driven engagement and their implications for urban and regional planning and management; and Section 4 presents our conclusions and underlines our contributions to contemporary academic discussion. 


\section{Review of concepts - spatially embedded family firms and corporate spatial responsibilities}

\section{Family firms in spatial context}

Although every economic entity is somehow situated or embedded in contexts (e.g., organizational, social, institutional) (Granovetter, 1985), spatial contexts have received very little academic attention in the realm of family firms, with some notable exceptions in recent years (Basco, 2015; Dana \& Ramadani, 2015; Seaman, 2015; Stough et al., 2015). The contemporary rediscovery of space in family business studies has led to emerging concepts of 'regional familiness' (Basco, 2015) and later, 'spatial familiness' (Basco \& Suwala, 2020a, b). According to Basco (2015, 267), regional familiness

incorporates the regional level into the concept of familiness by defining it as the embeddedness of family businesses in social, economic, and productive structures within a spatial context and the type of connections that emerge and interact with regional factors (...) and regional processes (...) through regional proximity dimensions.

Whereas 'regional familiness' favors a particular aggregational level (derived from the original concept of Habbershon \& Williams, 1999) and scale (obviously, the regional), 'spatial familiness' offers a much broader understanding of the phenomenon by considering the recursive relationship between family firms and spaces at different levels (e.g., individual, firm, firm groups). Spatial familiness also recognizes the simultaneous overlapping of multiple scales (e.g. local, global), as well as a broader scope of definitions of space that include locations, places and landscapes, among others (Suwala, 2019; Basco \& Suwala, 2020a, b).

Apart from that, different topics have been investigated in recent years, linking family firms to certain spatial entities like locational factors (e.g., Kahn \& Henderson, 1992); internationalization (e.g., Gallo \& Pont, 1996); specific spatial contexts like emerging markets (Basco, 2018) or transition economies (e.g., Duh, Tominc, \& Rebernik, 2009); different scales such as local (Baù, Block, Cruz, \& Naldi, 2017), regional (Bird \& Wennberg, 2014) and global (Yeung \& Soh, 2000) or various understandings of space (Suwala \& Schlunze, 2019). Therefore, it is not surprising that family firms are often tied to a specific spatial entity as the home region (e.g., Pongelli, Calabrò, \& Basco, 2019). Moreover, very few studies have considered family firms and their importance for spatial planning and/or policies (Basco \& Bartkevičiūtè, 2016; Albers \& Suwala, 2018) This relationship between family firms and spatial entities may exert various effects on the surrounding community in terms of philanthropy (Campopiano, De Massis, \& 
Chirico, 2014), community citizenship (Berrone, Cruz, Gomez-Mejia, \& Larraza-Kintana, 2012) or even regional business-led community development (Enright et al., 2016; Albers \& Suwala, 2020a). All efforts have resulted in a growing, but not coherent, body of research focusing on the nexus between family firms and spaces.

\section{Corporate spatial responsibility}

Whereas research on family firms is only beginning to systematically include spatial contexts, research in the field of corporate spatial responsibility (CSpR) has yet to dedicate much attention to the unique aspects of family firms. Corporate spatial responsibility (CSpR) is an extension of the well-known concept of corporate social responsibility (CSR). As a concept, CSpR emphasizes not only corporate engagement within a broader social context, but also within a particular spatial - usually urban or regional - setting. CSpR focuses mainly on cases where firms make social and ecological commitments to their surrounding environments that go beyond their core economic competencies (Albers, 2011; Albers \& Suwala, 2018, 2020b). In many ways, CSpR aligns with CSR principles embracing corporate ethics, social enterprise, corporate civic leadership, corporate and voluntary self-commitment and sometimes even corporate citizenship, to tackle manifold problems primary not connected with the principal economic activities of the firm (albeit those measures can be utilized for corporate objectives) (Hanson et al., 2010). What differentiates CSpR from CSR is the explicit spatial dimension and the respective commitment for locations or places at various scales (local, regional, urban, rural) (Knieling et al., 2012). We understand CSpR as a combined term for 'Corporate regional responsibility' (Schiek, 2017), 'Corporate urban responsibility' (Albers \& Hartenstein, 2017) and 'Corporate regional engagement' (Lengauer \& Tödtling, 2010). These predecessors locate CSR principles at particular spatial scales (Werna et al., 2009), whereas CSpR attempts to cover cases within any spatial context and any spatial process. Furthermore, existing disciplines tend to vary in their respective areas of focus, including the revitalization of the built environment (Albers, 2011), enhancing community life (Bürcher \& Mayer, 2018) or fostering sustainable urban development (Suwala \& Albers, 2020).

Earlier forms of the CSpR concept can be found in the period of industrialization when corporate or family firms financed urban (infra-) structures, supported local cultural and social institutions or constructed affordable housing for employees (e.g., Margarethenöhe [Germany, Ruhr by Alfred Krupp company dwelling estate] or Ford Homes in Detroit and Dearborn, US). Although traditional CSR instruments such as donations, sponsoring, patronage and charities are still widespread, novel measures such as public-private partnerships, corporate cooperation with the public sectors or civil society and long-term inter-institutional projects are on the rise (Albers \& Suwala, 2018). These complex instruments have often an explicit 
spatial dimension and impact (Albers \& Hartenstein, 2017). The variety of measures is far-flung, starting from simple firm-driven social, educational or recreational object-based building infrastructure (e.g., child-care centers) (Albers, 2011), revalorization (e.g., privately-owned spaces for public use, Kayden, 2000), relocation (e.g., corporate re-urbanization, Mozingo, 2011) or alteration of corporate premises (e.g., district renewal through cultural creative industries) (Suwala, 2015). Some of the most embedded practices range from involvement in business improvement districts or town center management schemes to more comprehensive private-sector-driven and business-community-led spatial development models (Hoyt, 2003; CocaStefaniak et al., 2009; Enright et al., 2016). These latter cases are particularly prevalent where there is a lack of consolidated government bodies or where public authorities display little effectiveness in pursuing development goals (Enright et al., 2016; Suwala et al., 2018).

\section{Family firms and corporate spatial responsibility}

Our aim in this section is to cross-fertilize insights from both emerging discourses in family firms in spatial context and in CSpR to enhance the understanding of family firm-driven engagement in various spatial settings. For this undertaking, we have to revisit literature that has already made a connection between family firms and CSR/CSpR to gauge in what circumstances and with what tools these approaches might overlap. Although caution should be exercised when linking concepts to new areas of application, family firm studies and regional engagement enjoy enough affinity to suggest a successful merging of disciplines. Regional engagement driven by family firms is a centuries-old activity with different degrees of commitment and versatile applications depending on institutional frameworks and economic systems (e.g., decentralized systems, such as the US and Germany, are more benign to family firms or family leaders in certain regions) (Stimson, Stough, \& Salazar, 2009; Hanson et al., 2010).

There is an elaborated research stream of family firms and CSR (e.g., Dyer \& Whetten, 2006), with studies focusing on the differences between the relationships of family vs. non-family firms with CSR (e.g., Cruz, Larraza-Kintana, Garcés-Galdeano, \& Berrone, 2014), the family ownership structure and CSR (Block \& Wagner, 2014), different types of CSR (e.g., philanthropy [Campopiano et al., 2014], corporate citizenship [Astrachan-Binz, Ferguson, Pieper, \& Astrachan, 2017], etc.) and family firms' social responsibility to communities (Niehm, Swinney, \& Miller, 2008), amongst others.

Concerning the question whether family firms are more socially responsible, Cruz et al. found that, given their socio-emotional wealth bias, they have more pronounced relationships with external stakeholders, yet neglect internal social dimensions. Moreover, they do not necessarily comply with national standards and industry conditions the way CSR measures of non-family firms do, but, rather, choose other activities (Cruz et al., 2014). This aligns with the ideas that 'family firms disseminate a greater variety of CSR reports, are less compliant with CSR standards and place emphasis on 
different CSR topics' (Campopiano \& De Massis, 2015, 511) and that they report less information on their CSR duties than non-family firms (Nekhili, Nagati, Chtioui, \& Rebolledo, 2017). The same study found that family firms would rather benefit from communicating their commitment to CSR, as they could obtain shareholders' support more easily than non-family firms (Nekhili et al., 2017, 41). In general, findings on whether family firms are more socially responsible or not are ambivalent depending on the size of the firm or field of commitment, among other factors (Cruz et al., 2014). With regard to family firm engagement in communities, Niehm et al. (2008) point to three dimensions - commitment to the community, community support, and sense of community - as striking features of family firm involvement.

In times of growing interactive and collaborative modes of governance, more attention needs to be paid to the socially responsible leadership question and its spatial context, especially at the regional or municipal level. Hence, space becomes a crucial factor. In this realm, family firms and CSR affects regions, cities, or rural communities and are affected by those spatial entities (Albers \& Suwala, 2018, 2020a). Devinney even calls for a

rethinking the meaning of space and place (...) as the rise of CSR is part and parcel of a more general phenomenon that is redefining the fundamental meaning of sociopolitical and economic geography. As corporations and economies have globalized, the sociopolitical structures have lagged behind.

(Devinney, 2011, 329, 339)

Interestingly, empirical studies dealing with family firms and CSR have largely ignored space or place with regard to both where family firms implement CSR and the impact of such initiatives on spatial entities (Albers \& Suwala, 2018). Space was rather considered a by-product, albeit a favorable one (e.g., in small rural communities [Niehm et al., 2008]; small business communities [Peake, Davis, \& Cox, 2015]; etc.). There are only few studies that explicitly deal with the relationship between family firms and CSpR - e.g., Albers and Suwala (2018, 2020b) and Graffenberger and Görmar (2020) considered family firm-driven engagement in and for spatial entities - leaving room for more research on the nature of 'space-based corporate responsibility of family firms'. For our research, the following guiding questions are of interest here: Firstly, how do family firms contribute to $C S p R$ ? Secondly, are there different intensities of family firm-driven engagement and how do those intensities relate to each other?

\section{Methodology}

In light of this theoretical background, we provide selected case studies of particular German-based family firms in order to shed light upon the great variety of their CSpR initiatives (first research question) and their impact/ 
intensity on spatial entities (second research question). Hereby, we utilize the CSpR maturity model that differentiates between 'degrees of responsibility/ spatiality' of CSPR measures (Albers \& Suwala, 2018, 55). Based on the CSR maturity model (Schneider, 2012), Albers and Suwala (2018) identified four different types of CSpR that vary according to the 'degrees of responsibility/ spatiality'. CSpR 0.0 and CSpR 1.0 encompass low-threshold/conventional engagement activities resulting from compliance with laws/rather accidental effects (CSpR 0.0) or philanthropic engagement (CSpR 1.0) with rather passive spatial impacts; both remotely (if at all) align with corporate objectives. CSpR 2.0 might possess a more systemic design that targets purposeful regional economic and societal synergies between the city/region and the family firm. Finally, CSpR 3.0 activities proactively interfere in duties once assigned to the public authority, or in matters of government with a clear spatial and societal impact (Albers \& Suwala, 2018, 2020b). Examples of CSpR 3.0 measures include, for example, the development of corporate spatial master plans or initiatives that cross-cut multiple areas of policy within the territorial domain of public authorities.

The analysis of the relationship between family firms and CSpR, both in the form this relationship takes and in terms of the intensity of its spatial impact, is based on a selection of case studies of corporate spatial engagement of German family firms. This selection rests on a continuous monitoring of CSR activities in the context of urban and regional development over the past 10 years; the evaluation of relevant studies, databases and research work and the authors' participation in several research projects. For the case study selection, three methodological steps were taken into account. First, the choice of examples rested on 'purposive sampling' (Patton, 2001) where selected examples were either easily accessible or where personal participation was involved. Second, the relevance of examples was checked by analyzing their frequency in daily press and academic journals. Third, the variety of examples was ensured by the 'go for polar types' approach (Meredith, 1998) in order to identify different degrees (e.g., extreme cases, typical cases, maximum variation of cases, intensity sampling, critical cases, politically important or sensitive cases, etc.) of CSpR initiatives of family firms. Since our background is in regional and CSpR studies, we grouped different CSpR measures of family firms according to their degree of 'degrees of responsibility/spatiality'. For this assessment, the pyramid in Figure 12.1 gives insight into how we can link and classify different types and intensities of family firm CSpR. We have elected to pursue a plausible rather than a representative approach, in which cases were chosen based on their accessibility rather than their claim to representativeness.

\section{Analysis}

The following analysis presents selected case studies of family firms engaged in urban and regional initiatives. It attempts to classify those examples into 


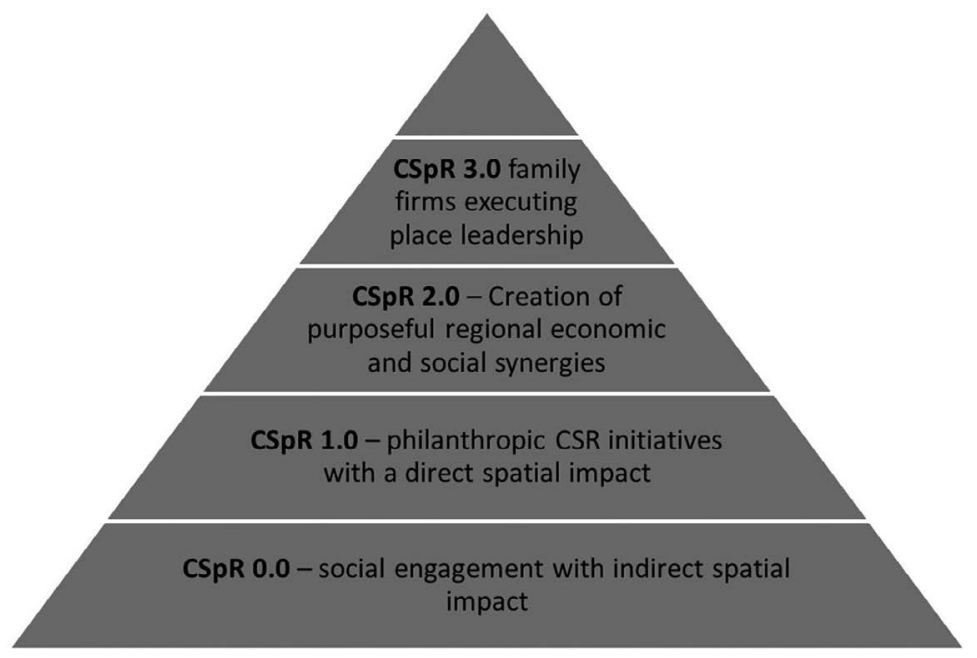

Figure 12.1 Family firms and the corporate spatial responsibility model. Source: Adapted from Albers and Suwala (2018), 55 based on Schneider (2012).

four types of engagements based on the above-mentioned CSpR maturity model (Figure 12.1). The first step of this analysis will be to show different examples and forms of CSpR initiatives by family firms. In a second step, these examples will be classified based on spatial intensities. The analysis is not intended to be exhaustive, but to illustrate plausible links between family firms and CSpR initiatives.

\section{Family firms and the sponsoring of social, educational or recreational infrastructure}

One traditional model of regional engagement by family firms is regional philanthropy, such as the financing or promoting buildings for social, educational or recreational purposes (Feliu \& Botero, 2016). In the 19th century, donations for art and cultural buildings helped cities develop a new civic identity. This tradition is still widespread among business patrons and family firms and, in addition to prestige for donors, is also intended to enhance the image of cities and their centers (Rectanus, 2002). A modern interpretation of this mechanism is the so-called the 'Bilbao Effect' (named after the Guggenheim Museum built in the Basque city of Bilbao by Frank Gehry) (Plaza, 2008). The term describes the general strategic use of icons (symbolic buildings) in order to revive a city economically and culturally (Suwala, 2014). This effect acts as a role model and has been also used for partly or fully family firm-financed art projects since then. In what follows, we want to showcase some examples from the German context. 
In the city of Herford (North Rhine-Westphalia, 67,000 inhabitants), the local furniture industry, mostly driven by family firms, mutually commenced a corporate initiative with local politicians and the famous architect Gehry to realize the Marta Herford project (a Bilbao-inspired art museum) based on an impressive selection of works by contemporary artists of a local family firm owner and art collector. In Hamburg, the construction of the Elbe Philharmonic Hall (the city's new landmark) was partly founded on a donation initiative by the city's family entrepreneurs. Other cases particularly in smaller German cities show that family firms or their owners (frequently world market leaders in certain economic niches) are often the driving forces behind such initiatives. Cultural buildings sponsored by family firms are used to brand city centers (e.g., the Kunsthalle Weishaupt in Ulm, the Museum Barberini in Potsdam [Hasso Plattner, SAP] or the Knauff Museum in Iphofen). All these projects are based on a strong site solidarity of the CEOs or family members (with a prolonged locational entanglement) and have similar expressions in countries outside Germany (Albers, 2011; Basco et al., 2020; Suwala \& Albers, 2020).

Apart from these philanthropic, branding initiatives, family firms are increasingly investing in local built infrastructure, especially in educational or recreational facilities for use by their employees and the surrounding citizenry. In one example, the company Stihl is building a daycare center in Waiblingen to serve not only their employee's children, but also children in the surrounding neighborhoods. These efforts are often meant to attract employees, enhance quality of life and recruit new graduates. A similar trend can be seen in the renaissance of company-financed and owned dwellings. In Memmingen (Bavaria, 44,000 inhabitants), Häussler, a family firm that runs a bakery chain, is planning to build employee apartments at the company headquarters. As the lack of affordable housing continues to be a growing problem in many German cities, companies whose employees find it difficult to find nearby homes are investing in this housing themselves. Although many of these initiatives have a mediate effect on regional development, this broader impact is seldom the intention of the engagement.

\section{Family firms and their impact on re-urbanization, district renewal and privately owned public spaces}

Another type of spatial engagement driven by family firms is founded by corporate support for urban renewal and individual public space initiatives and is best understood in light of changing urban spatial dynamics over the last few decades (Albers \& Suwala, 2020b). Most contemporary cities host a series of competing urbanizations and increasingly complex urban migration patterns of both residential and commercial uses. Departing from the well-known 'doughnut effect' where many cities and municipalities are struggling with deteriorating centers and where retail moves to shopping centers, industry is migrating to business parks and new housing is being created in 
many places on the outskirts (Sternlieb \& Hughes, 1980); setting up activities around cultural creative districts such as the aforementioned familydriven commitment to art and cultural buildings is a first step (Suwala, 2015). A more developed approach, however, is family firm re-urbanization, where companies move back to city centers, directly or indirectly leading to local economic development, for example, for the revitalization of centers (e.g., corporate family firm campuses or universities). There are instances of big U.S. corporations, some of them family firms, that have recently returned to city centers after decades of corporate suburbanization (Mozingo, 2011). Although firms often have clear business-related incentives for this geographical return, in particular to attract young workers, particularly interesting cases emerge when corporations move into certain areas with the intention of contributing to local economic and community development and city revitalization (Sutton, 2010).

One example from Germany can be found in Mertingen (Bavaria, approx. 4,000 inhabitants). The town center of Mertingen is currently undergoing remodeling. Zott (a family firm founded in 1926 with around 3,000 employees currently and one of the leading dairy production companies in Europe) serves as an important economic player in the region. Supported by the Ministry of Construction of the Free State of Bavaria, the corporate initiative attempts to revitalize the town center and turn it into a lively and attractive place. Zott is modernizing parts of its inner-hamlet old premises, relocating their headquarters and administration here. In addition, the project initiates further developments such as the conversion of the main square or the refurbishment of adjacent buildings.

A further characteristic of some cases of re-urbanization by family firms is the integration and opening of corporate space for public use (Albers \& Suwala, 2018). This phenomenon reflects an old trend starting in the 1950s in the dense urban fringes of central business districts in global cities (New York, Tokyo, Hong Kong and new metropoles in China), called 'privately owned public spaces', where large corporations were opening up their properties in manifold ways to the public (e.g., as arcades, urban plazas, through blocks or covered pedestrian spaces, etc.) (Kayden, 2000).

\section{Family firms' interest in business improvements districts, town-center management and family firm-led master plan initiatives}

The engagements that we have discussed so far have been focused on the implementation of spatial measures, either through the sponsorship of individual buildings or urban infrastructure or by participating in broader reurbanization-based development schemes. But some family firms are also involved in more strategic tasks of urban management in a variety of spatial contexts. These include direct involvement in planning processes on a district level, as well as in business improvement districts, in town center 
management schemes or in the preparation of spatial master plans for the city or region (e.g., Hoyt, 2003; Albers \& Suwala, 2018). This is far from new. The Plan of Chicago or the Burnham Plan of 1909 is considered the most famous example of a master plan initiated by the private sector. The plan was commissioned by the Commercial Club of Chicago, however, it was only partially implemented. The principal aim and purpose of the initiative was to ensure the city's functionality and competitiveness (cf. Burnham \& Benett, 1909). These examples are still relevant today and appear in manifold ways, varying in intensity and obligation and the extent to which family firms are involved.

A first mode, originating in Canada and the U.S. from the 1970s on, are business improvement districts (given similar names depending on the country; e.g., 'downtown improvement districts' in Japan, 'main street associations' in New Zealand [Hoyt, 2003], etc.). Business improvement districts are among the most widespread initiatives in local governance and represent a geographically defined area where the majority of property owners and/or merchants agree to provide an enhanced level of public service by imposing an additional tax or fee on all the properties and/or businesses in the area (Mitchell, 2001). The idea is to 'channel private-sector energy toward the solution of public problems' (MacDonald, 1996, 42). Studies from Germany have shown that family firms are slowly starting to support business improvement districts by marketing downtown districts, providing additional infrastructure (e.g., sanitation and security services), advocating public policies that promote downtown interests and acting as drivers of urban regeneration (Faller \& Wiegandt, 2010). A second similar but citywide mode is town-center management, which can be roughly defined as 'a coordinated pro-active initiative designed to ensure that (...) city centres are desirable and attractive places. In nearly all instances the initiative is a partnership between the public and private sectors and brings together a wide-range of key interests' (Coca-Stefaniak et al., 2009, 75). An interesting case study is 'Berlin Partner', which is a unique public-private partnership set up by the Berlin State Senate and over 280 firms (many of them family run), dedicated to promote marketing, city business and technology support for companies, investors and scientific institutions in the German capital.

A third mode, and probably the most influential one in family firm-driven regional engagement, are so-called private sector-led master plan initiatives (Morrison, Wilson, \& Bell, 2012; Albers \& Suwala, 2018). These initiatives inherit a 'combination of district, city and state authorities or government agencies on issues from business conditions to a city's broad long-term agenda' (Enright et al., 2016, 3). Here, the private sector or family firms initiate far-flung regional development measures in cities where there is discontent with planning frameworks but that have a robust business presence or weak/consolidated city authorities. Weak authorities manifest for various reasons (e.g., fragmented or localized authorities, subject to control from 
strong regional or national authorities, a lack of advanced infrastructure or insufficient investment, tax income or spending power). Such a measure in the German context is the so-called business association 'Unternehmer für die Region Köln' (many of them family firms). Together with the Chamber of Commerce of Cologne, they charged a famous architectural office with drafting a master plan for the city. Two further master plan initiatives initiated by the private sector have recently attracted considerable attention in Germany. In Mönchengladbach (North Rhine-Westphalia) a master plan was created in 2012/2013 with financing from local (family) firms (https:// mg3-0.de). All initiatives were subsequently confirmed by the city council after public hearings and have since then become the de facto 'official' urban development concepts.

Our final example encompasses a business community-led model initiated by a single-family firm and executed through a private sector-driven urban development agency. The Duderstadt 2020 initiative is the idea of the family entrepreneur Hans Georg Näder (owner \& CEO of Otto Bock $\mathrm{GmbH}$ from Duderstadt, a mid-size town in Lower Saxony, Germany; the company is the world market leader in orthopedics). The project has been developed and organized by a team from the regional University of Applied Sciences (HAWK) since 2009. Against this background, a limited company (Duderstadt2020 GmbH) was founded to guide this initiative and to strengthen the attractiveness of the town (e.g., by boosting amenities, quality of life, employment). The process comprised the following consolidated actions: setting up a master plan, strengthening networks (e.g., corporate, public and civic among different stakeholders), stimulating citizen participation (such as discussion forums, future workshops, etc.) and fostering neighborhood development, among many others. In the meantime, Duderstadt2020 is regarded as the city's urban development agency that traces an 'integrative urban development management' within six areas of interest (urban marketing, tourism promotion, economic promotion, cultural promotion, neighborhood development and social interaction). Most recently, the Duderstadt 2030 city vision and the 'Futuring Duderstadt' master plan were presented (Albers \& Suwala, 2020b).

\section{Intensities of spatial engagement by family firms}

In this section, we will compare the types and intensities of the spatial engagements by family firms that were traced in the sections above. In the "Family firms and the sponsoring of social, educational or recreational infrastructure" section, we looked at examples of family firms and their sponsorship of social, education or recreational facilities within their local spatial setting.

These activities, although they sometimes have extenuated spatial impacts, are usually not pursued for their effects on the spatial environment. For this reason, they are more in line with traditional CSR activities. Spatial effects are usually dependent on the type of built infrastructure and its 
particular spatial radiance (compare, for example, an art museum and a kindergarten). Architectural icons are often guided by patronage and personal motives of the family entrepreneurs or their firms; they rather represent traditional philanthropic initiatives and, if they exert any spatial impact at all, this is usually indirectly, as flagship projects for promoting or reviving a city or district. These types of initiatives correlate to levels CSpR 0.0 or CSpR 1.0 from the CSpR maturity model (Figure 12.1).

In the "Family firms and their impact on re-urbanization, district renewal and privately owned public spaces" section, we highlighted projects where firms are engaged more comprehensively with their spatial surroundings. By offering private spaces for public use, or by committing to large-scale financial or locational investments for reurbanization and revitalization purposes, family firms, often in cooperation with municipalities, have a much clearer and substantial link to urban and regional development. In these cases, the needs of the city or district and the requirements of the company coalesce; the city's desire to ease the local housing market, for example, can be met by private firms supplying workers with firm-owned housing. Still, there are varying degrees of spatial impact here. Permitting public use of firm-owned spaces, for example, has a more locally confined spatial impact than relocating a corporate headquarter, which in many cases has a tremendous effect on entire villages or urban districts. The Mertingen case also shows a family firm acting as a main driver for urban revitalization, especially in situations where public funding, collaborative know-how and companies' sensitization for local issues abound. In the most integrated cases, these measures can unfold into purposeful regional economic and societal synergies and help to contribute to win-win development scenarios. These cases correspond to the classification CSpR 2.0. Often, however, the examples laid out in the "Family firms and their impact on re-urbanization, district renewal and privately owned public spaces" section still fall into the classification of CSpR 1.0.

The "Family firms' interest in business improvements districts, towncenter management and family firm-led master plan initiatives" section details a number of cases where family firms are engaged in strategic local or regional engagement and mid-term regional planning. Included in these cases are firms' involvement in business improvement districts, town center management schemes and private sector-led master plan initiatives. On average, these cases display a much higher impactfulness on urban and regional planning and management, as well as on the surrounding spatial environments. Moreover, all measures of this variety have an explicit spatial focus and fulfill many of the criteria outlined for CSpR 2.0. Often these initiatives are led by associations of proactive firms rather than individual companies and are willing and able to design, finance and lead certain processes within their spatial setting. Generally speaking, this type of engagement by family firms unfolds much more effectively if the public sector is involved to advise and steer activities, at least in German cases. Participation 
of the civil sector is also an important indicator for general success. This not only leads to more comprehensive inclusion of stakeholders, but also helps private sector-driven initiatives to gain credibility for their actions and plans. Because many of these initiatives have a trans-sectoral focus (i.e. they target not only economic but also cultural, educational, social or developmental issues), they are usually most successful when they integrate a cross-institutional, systemic, long-term approach. Accordingly, they often lead to significant place leadership by the family firms involved. All master plan initiatives laid out in our analysis fit the criteria for intentional CSpR 3.0 measures. They have far-reaching implications for residential, commercial and industrial planning, as well as for land use, the built environment and far-reaching spatial implications within the wider regional community. The commitment is often sustained by the existence of independent private sector-driven urban development agencies set up as autonomous legal entities (see Figure 12.1).

Based on the cases above, we think that our classification of CSpR fits appropriately to family firms. Many possible exceptions exist, however, that would require a deeper case-by-base analysis. One could imagine, for example, a family firm engaged in frequent and extensive philanthropic sponsorship but without a comprehensive spatial thread or strategic aspirations, despite the great financial commitment. Furthermore, some spatially impactful initiatives, such as the allowance of public usage of private land or involvement in a business improvement district, may be legally mandated by local zoning or building code ordinances and may therefore not fulfill the criteria of CSpR at all on account of being non-voluntary.

\section{Conclusion}

Our goal was to answer two questions about family firms and corporate spatial responsibility, namely how (forms) and to what extent (their spatial impact/intensity) family firms implement CSpR measures, or in other words whether family firms are spatially responsible. We have been able to show that family firms are spatially engaged in manifold and unique ways and with varying intensities. Examples above ranged from CSpR 0.0, engagement which demonstrates little to no spatiality, to CSpR 3.0, where corporate engagement has strategic, far-reaching and long-lasting spatial impacts. $\mathrm{CSpR}$ adds to the regional policy toolbox by establishing alternative models for local and regional engagement, development and governance. This becomes even more spatially salient when family firms are involved in the design, implementation, participation and even leadership of these activities. The main feature of this engagement is the regional orchestration and framing of activities by family firms - in tandem with state authorities - in order to foster economic development or other favorable outcomes in the region. These models align with the rise of non-state 'place-based' economic 
development strategies at a time when state and society at large are more reliant on non-state actors (Albers, 2011; Harrison, 2014). CSpR initiatives by the private sector and by family firms are constantly exposed to nuanced and manifold critiques in accordance with their placement within rising neoliberal tendencies of spatial planning and management and an increasing hesitancy surrounding corporate influence of the public sphere (e.g. Ward, 2006). Our examples demonstrate this fear is in part comprehensible (take, for example, the widespread influence of the family entrepreneur in Duderstadt), especially if the civic sector is not appropriately included or even intentionally is neglected from strategic planning measures (as was the case in Masterplan Cologne).

Notwithstanding, we think that a coordinated and appropriate level of regional engagement by family firms can create synergies for communities and the spatial setting in which firms operate. Moreover, in small towns or rural areas, or in jurisdictions lacking consolidated government bodies or demonstrating low effectiveness of public authorities, family firm-driven community development may be without alternatives (Horlings \& Padt, 2013; Suwala et al., 2018). By considering family firms and their corporate spatial responsibilities in Germany, we have sought to contribute to theoretical, practical and policy-based conceptualizations of this phenomenon. We have provided examples for different degrees of corporate spatial responsibility as performed by family firms, expanding the spatial dimension within research of family firms and corporate social responsibility (Campopiano et al., 2014; Campopiano \& De Massis, 2015). Practically speaking, understanding the role of family firms in CSpR initiatives adds to the regional policy toolboxes that stakeholders use to enact urban and regional change. Still, our analysis provides only an overview of possible spatial embeddings of family firms' engagements (for other types, see Selcuk \& Suwala, 2020). In cases of practical application, this analysis needs to be appropriately tailored to the respective modes of governance, economic systems, social norms and regional particularities. Finally, this chapter demonstrates the strategic nature of family firms' engagement with CSpR and the resulting implications this can have for urban and regional planning and management. We emphasize the importance of tri-sectoral negotiations (between family firms, the state and civic society) to ensure the effectiveness and value of these initiatives; only transparency, communication, reciprocity and a mutual sensitivity to the needs of partners will allow problems to be solved. By enlisting family firms into CSpR policy, policy makers have the ability to increase confidence within the private sector and unleash the potentials of the strong connection family firms tend to have with their home regions (Bird \& Wennberg, 2014; Basco et al., 2020). Future lines of thinking and research could either concentrate on some of the specific ways in which family firms can engage in $\mathrm{CSpR}$, or could conduct a cross-country comparison of best practices in this field to provide policy makers with a better understanding of when, why, how and under which circumstances family firms should be integrated within spatial development agendas. 


\section{References}

Albers, H.-H. (2011). Corporate Urban Responsibility. Frankfurt: Campus.

Albers, H.-H., \& Hartenstein, F. (2017). (Eds.), CSR und Stadtentwicklung: Unternehmen als Partner für eine nachhaltige Stadtentwicklung. Berlin: Springer.

Albers, H.-H., \& Suwala, L. (2018). Unternehmensengagement als Standortfaktor. Mit der Wirtschaft attraktive (Klein-)Städte schaffen. Informationen zur Raumentwicklung, 6, 50-57.

Albers, H.-H., \& Suwala, L. (2020a). Place leadership and corporate spatial responsibilities. In M. Sotarauta \& A. Beer (Eds.), Handbook on City and Regional Leadership. Cheltenham: Edward Elgar Publishing.

Albers, H.-H., \& Suwala, L. (2020b). Räumliches Unternehmensengagement (corporate spatial responsibility) und Ortsführung (place leadership) in Kleinstädten. Perspektiven für eine neue Ortsführung? Eine Zusammenführung von zwei Diskursen. In S. Döhringer \& J. Eder (Eds.), Schlüsselakteure der Regionalentwicklung. Welche Perspektiven bietet Entrepreneurship für ländliche Räume? (pp. 63-84). Wien: ISR Forschungsbericht. Band 51.

Astrachan-Binz, C., Ferguson, K. E., Pieper, T. M., \& Astrachan, J. H. (2017). Family business goals, corporate citizenship behaviour and firm performance: Disentangling the connections. International Journal of Management and Enterprise Development, 16(1-2), 34-56.

Basco, R. (2015). Family business and regional development - A theoretical model of regional familiness. Journal of Family Business Strategy, 6(4), 259-271.

Basco, R. (2018). Family business in emerging markets. In R. Grosse \& K. E. Meyer (Eds.), The Oxford Handbook of Management in Emerging Markets (pp. 1-22). Oxford: Oxford University Press.

Basco, R., \& Bartkevičiūte, I. (2016). Is there any room for family business into European Union 2020 strategy? Family business and regional public policy. Local Economy, 31(6), 709-732.

Basco, R., Stough, R., \& Suwala, L. (2020). (Eds.), Family Business and Regional Development. London: Routledge.

Basco, R., \& Suwala, L. (2020a). Spatial familiness - A bridge between family business and economic geography. In A. Calabò (Ed.), A Research Agenda for Family Business: A Way Ahead for the Field (pp. 185-202). Northampton, MA: Edward Elgar Cheltenham.

Basco, R., \& Suwala, L. (2020b). Spatial familiness and family spatialities - Searching for fertile ground between family business and regional studies. In R. Basco, R. Stough, \& L. Suwala (Eds.), Family Business and Regional Development. London: Routledge.

Baù, M., Block, J. H., Cruz, D. A., \& Naldi, L. (2017). Locality and internationalization of family firms. Entrepreneurship \& Regional Development, 29(5-6), 570-574.

Berrone, P., Cruz, C., Gomez-Mejia, L. R., \& Larraza-Kintana, M. (2012). Socioemotional wealth and corporate responses to institutional pressures: Do familycontrolled firms pollute less? Administrative Science Quarterly, 55(1), 82-113.

Bird, M., \& Wennberg, K. (2014). Regional influences on the prevalence of family versus non-family start-ups. Journal of Business Venturing, 29(3), 421-436.

Block, J., \& Wagner, M. (2014). Ownership versus management effects on corporate social responsibility concerns in large family and founder firms. Journal of Family Business Strategy, 5(4), 339-346. 
Bürcher, S., \& H. Mayer (2018). Are there differences in social capital related to corporate regional engagement in dynamic and less dynamic non-core regions? European Planning Studies, 26(2), 342-364.

Burnham, D. H., \& Bennett, E. H. (1909). Plan of Chicago. New York: Princeton Architectural Press.

Campopiano, G., \& De Massis, A. (2015). Corporate social responsibility reporting: A content analysis in family and non-family firms. Journal of Business Ethics, 129(3), 511-534.

Campopiano, G., De Massis, A., \& Chirico, F. (2014). Firm philanthropy in smalland medium-sized family firms: The effects of family involvement in ownership and management. Family Business Review, 27(3), 244-258.

Cruz, C., Larraza-Kintana, M., Garcés-Galdeano, L., \& Berrone, P. (2014). Are family firms really more socially responsible? Entrepreneurship Theory and Practice, 38(6), 1295-1316.

Coca-Stefaniak, J. A., Parker, C., Quin, S., Rinaldi, R., \& J. Byrom (2009). Town centre management models: A European perspective. Cities, 26(2), 74-80.

Dana, L. P., \& Ramadani, V. (2015). Family Businesses in Transition Economies. Cham: Springer.

Devinney, T. M. (2011). Social responsibility, global strategy, and the multinational enterprise: Global monitory democracy and the meaning of place and space. Global Strategy Journal, 1(3-4), 329-344.

Duh, M., Tominc, P., \& Rebernik, M. (2009). The importance of family enterprises in transition economies: Is it overestimated? Eastern European Economics, 47(6), 22-42.

Dyer Jr, W. G., \& Whetten, D. A. (2006). Family firms and social responsibility: Preliminary evidence from the S\&P 500. Entrepreneurship Theory and Practice, 30(6), 785-802.

Enright, M., Hunziker, R., Mendle, R., Reemes, J., \& Vancutsem, D. (2016). How Cities and Business Can Work Together for Growth. Global Cities Business Alliance. Discussion Paper. Retrieved from https://www.pwc.com/gx/en/psrc/pdf/gcbacities-business-growth.pdf.

Faller, B., \& Wiegandt, C. C. (2010). Die geschenkte Stadt. In Mäzenatentum in der deutschen Stadtentwicklung. Forum Wohn Stadtentwicklung, Dezember, 329-336.

Feliu, N., \& Botero, I. C. (2016). Philanthropy in family enterprises: A review of literature. Family Business Review, 29(1), 121-141.

Gallo, M. A., \& Pont, C. G. (1996). Important factors in family business internationalization. Family Business Review, 9(1), 45-59.

Graffenberger M., \& Görmar F. (2020), Family firms and corporate responsibility in peripheral regions. In R. Basco, R. Stough, \& L. Suwala (Eds.), Family Business and Regional Development. London: Routledge.

Granovetter, M. (1985). Economic action and social structure: The problem of embeddedness. American Journal of Sociology, 91(3), 481-510.

Habbershon, T., \& Williams, M. (1999). A resource-based framework for assessing the strategic advantages of family firms. Family Business Review, 12(1), 1-25.

Hanson, R., Wolman, H., Connolly, D., Pearson, K., \& McManmon, R. (2010). Corporate citizenship and urban problem solving: The changing civic role of business leaders in American cities. Journal of Urban Affairs, 32(1), 1-23.

Harrison, J. (2014). The rise of the non-state 'place-based' economic development strategy, Local Economy, 29(4-5), 453-468. 
Horlings, I., \& Padt, F. (2013). Leadership for sustainable regional development in rural areas: Bridging personal and institutional aspects. Sustainable Development, 21(6), 413-424.

Hoyt, L. M. (2003). The Business Improvement District: An Internationally Diffused Approach to Revitalization. Cambridge, MA: MIT Press.

Kahn, J. A., \& Henderson, D. A. (1992). Location preferences of family firms: Strategic decision making or "home sweet home"? Family Business Review, 5(3), 271-282.

Kayden, J. (2000). Privately Owned Public Space: The New York City Experience. New York: John Wiley \& Sons.

Knieling, J., Othengrafen, F., \& Preising, T. (2012). Privatisierung von Stadt- und Regionalentwicklung: Gesellschaftlicher Nutzen oder Verwirklichung von Unternehmenszielen? "Corporate Spatial Responsibility" or "Corporate Spatial Strategy"? Raumforschung und Raumordnung, 70(5), 451-464.

Lengauer, L., \& Tödtling, F. (2010). Regional Embeddedness and Corporate Regional Engagement: Evidence from Three Industries in the Austrian Region of Styria. Paper Presented at the 8th European Urban \& Regional Studies Conference, Vienna, September 15-17.

MacDonald, H. (1996). BIDs really work. City Journal, 6(2), 29-42.

Meredith, J. (1998). Building operations management theory through case and field research. Journal of Operations Management, 16(4), 441-454.

Mitchell, J. (2001). Business improvement districts and the "new" revitalization of downtown. Economic Development Quarterly, 15(2), 115-123.

Morrison, T. H., Wilson, C., \& Bell, M. (2012). The role of private corporations in regional planning and development: Opportunities and challenges for the governance of housing and land use. Journal of Rural Studies, 28(4), 478-489.

Mozingo, L. A. (2011). Pastoral Capitalism: A History of Suburban Corporate Landscapes. Cambridge, MA: MIT Press.

Nekhili, M., Nagati, H., Chtioui, T., \& Rebolledo, C. (2017). Corporate social responsibility disclosure and market value: Family versus nonfamily firms. Journal of Business Research, 77, 41-52.

Niehm, L. S., Swinney, J., \& Miller, N. J. (2008). Community social responsibility and its consequences for family business performance. Journal of Small Business Management, 46(3), 331-350.

Patton, M. Q. (2002), Qualitative Research and Evaluation Methods (3rd ed.). Thousand Oaks, CA: Sage.

Peake, W. O., Davis, P. E., \& Cox, M. Z. (2015). Being good for goodness sake: The influence of family involvement on motivations to engage in small business social responsibility. Journal of Small Business Strategy, 25(1), 1-25.

Plaza, B. (2008). On some challenges and conditions for the Guggenheim Museum Bilbao to be an effective economic re-activator. International Journal of Urban and Regional Research, 32(2), 506-517.

Pongelli, C., Calabrò, A., \& Basco, R. (2019). Family firms' international makeor-buy decisions: Captive offshoring, offshore outsourcing, and the role of home region focus. Journal of Business Research, 103, 596-606.

Rectanus, M. (2002). Culture Incorporated: Museums, Artists, and Corporate Sponsorships. Minneapolis: University of Minnesota Press.

Schiek, M. (2017). Corporate Regional Responsibility (CRR). Lemgo: Rohn. 
Schneider, A. (2012). Reifegradmodell CSR - Eine Begriffserklärung und Abgrenzung. In A. Schneider \& R. Schmidpeter (Eds.), Corporate Social Responsibility, Verantwortungsvolle Unternehmensführung in Theorie und Praxis (pp. 17-38). Berlin: Springer Gabler.

Seaman, C. (2015). Creating space for the business family: Networks, social capital \& family businesses in rural development. Journal of Family Business Management, 5(2), 182-191.

Selcuk, G., \& Suwala, L. (2020). Migrant Family entrepreneurship - Mixed and multiple embeddedness of transgenerational Turkish family entrepreneurs in Berlin. Journal of Family Business Management. Forthcoming.

Sternlieb, G., \& Hughes, J. W. (1980). The changing demography of the central city. Scientific American, 243(2), 48-53.

Stimson, R., Stough, R. R., \& Salazar, M. (2009). Leadership and Institutions in Regional Endogenous Development. Northampton: Edward Elgar.

Stough, R., Welter, F., Block, J., Wennberg, K., \& Basco, R. (2015). Family business and regional science: "Bridging the gap." Journal of Family Business Strategy, 6(4), 208-218.

Sutton, S. A. (2010). Rethinking commercial revitalization: A neighborhood small business perspective. Economic Development Quarterly, 24, 352-371.

Suwala, L. (2014). Kreativität, Kultur und Raum: Ein wirtschaftsgeographischer Beitrag am Beispiel des kulturellen Kreativitätsprozesses. Berlin: Springer-Verlag.

Suwala, L. (2015).Cultural districts. In F. Frank Wherry \& J. Julie Schor (Eds.), The Sage Encyclopedia of Economics and Society (pp. 511-513), Thousand Oaks, CA: Sage.

Suwala L. (2019). Management Geography - Standortentscheidungen, Netzwerke und Raumbilder nordamerikanischer und japanischer Familienunternehmen.

Suwala L. \& Albers H.H. (2020). Corporate Spatial Responsibility and Sustainable Development Goals. In: Leal Filho W., Azul A., Brandli L., Lange Salvia A., Wall T. (eds) Decent Work and Economic Growth. Encyclopedia of the UN Sustainable Development Goals. Springer, Cham. https://doi.org/10.1007/978-3-319-71058-7_129-1

Suwala, L., Kulke, E., \& Gade, K. (2018). Zentralamerika (Nicaragua, Honduras, Guatemala, Belize) - Bericht zur Hauptexkursion 2017. Berlin: Arbeitsberichte Geographisches Institut Heft 195.

Suwala, L., \& Schlunze, R. (2019). The stony path of management geography. SIEM Bulletin, 1(1), 1-5.

Ward, K. (2006). Policies in motion, urban management and state restructuring: The trans-local expansion of business improvement districts. International Journal of Urban and Regional Research, 30(1), 54-75.

Werna, E., Keivani, R., \& Murphy, D. (2009). Corporate Social Responsibility and Urban Development Lessons from the South. Basingstoke: Palgrave Macmillan.

Yeung, H. W. C., \& Soh, T. M. (2000). Corporate governance and the global reach of Chinese family firms in Singapore. Seoul Journal of Economics, 13(3), 301-334. 